\title{
Thrips Resistance in Pepper and Its Consequences for the Acquisition and Inoculation of Tomato spotted wilt virus by the Western Flower Thrips
}

\author{
P. C. Maris, N. N. Joosten, D. Peters, and R. W. Goldbach
}

Laboratory of Virology, Wageningen University, Binnenhaven 11, 6709 PD Wageningen, the Netherlands. Accepted for publication 3 September 2002.

\begin{abstract}
Maris, P. C., Joosten, N. N., Peters, D., and Goldbach, R. W. 2003. Thrips resistance in pepper and its consequences for the acquisition and inoculation of Tomato spotted wilt virus by the western flower thrips. Phytopathology 93:96-101.

Different levels of thrips resistance were found in seven Capsicum accessions. Based on the level of feeding damage, host preference, and host suitability for reproduction, a thrips susceptible and a resistant acces-

in a broad range of acquisition access periods. Inoculation efficiency was also not affected in short inoculation periods, but was significantly lower on plants of the thrips resistant accession during longer inoculation access periods. Under the experimental conditions used, the results obtained show that transmission of TSWV is little affected by vector resistance. However, due to a lower reproduction rate on resistant plants and a lower preference of thrips for these plants, beneficial effects of vector resistance might be expected under field conditions.
\end{abstract} sion were selected to study their performance as Tomato spotted wilt virus (TSWV) sources and targets during thrips-mediated virus transmission. Vector resistance did not affect the virus acquisition efficiency
Additional keywords: Capsicum annuum, Frankliniella occidentalis, vector resistance, virus transmission.
Thrips (Thysanoptera: Thripidae) cause serious problems in the cultivation of a wide range of greenhouse and field crops. They create major damage on plants by causing reduction in plant growth, deformation of plant organs, and cosmetic damage in the form of silver scars on leaves and flowers. Moreover, during feeding, thrips may transmit tospoviruses (family Bunyaviridae) $(27,31,39)$, of which Tomato spotted wilt virus (TSWV) is economically the most important representative (13). Several thrips species, belonging to the genera Thrips and Frankliniella transmit TSWV. The western flower thrips (Frankliniella occidentalis) is thought to be the most predominant and effective vector in many parts of the world $(10,32,36)$.

Attempts to impede tospovirus spread by chemical control of its vectors has proven to be difficult due to the development of vector resistance to insecticides $(9,25,41)$, the polyphagous behavior of thrips, and their often hidden way of life inside flowers where they can escape from insecticides sprayed. In addition, TSWV cannot efficiently be controlled in some crops by application of insecticides as the virus often spreads by incoming adults. These thrips may transmit the virus before they acquire a deadly dose of insecticides $(17,30)$. Moreover, there is increasing public demand to develop alternative control measures, as the practical use of most of the potentially effective pesticides is no longer allowed in an increasing number of countries.

The use of virus and/or vector resistant cultivars is another option to control TSWV. Virus resistance has been reported in accessions of pepper and tomato $(5,14,15,26,29)$, and a single dominant TSWV resistance trait has been described for pepper (6). This gene, designated $T s w$, has been introduced in a number of cultivated Capsicum hybrids (7). An operational level of thrips resistance (toward $F$. schultzei) has been reported in the groundnut

Corresponding author: D. Peters; E-mail address: dick.peters@wur.nl

Publication no. P-2002-1106-01R

(C) 2003 The American Phytopathological Society cv. Robut 33-1 (2). The incidence of Groundnut bud necrosis virus (GBNV) was 30 to $60 \%$ lower in this cultivar than in the widely used cv. TMV2, although both cultivars were equally susceptible to this tospovirus by mechanical inoculation. Since the acquisition and transmission rate by thrips did not differ between these cultivars, the lower incidence in the field was explained by a lower preference of $F$. schultzei for 'Robut 33-1'. This type of resistance, restricting the spread of a given virus and often designated "field resistance", was also observed for TSWV in tomato $(15,16)$. Significantly fewer plants of four Lycopersicon cultivars became infected with TSWV by thrips inoculations than by mechanical inoculation (15), indicating that vector-mediated components were involved. Partial resistance against $F$. occidentalis has also been reported for five pepper accessions (12). However, this resistance was not evaluated with respect to its effect on the spread of TSWV in the field or on the virus acquisition and inoculation efficiencies of the thrips. Hence, despite several reports, the effect of plant resistance to thrips on transmission of TSWV is not fully understood and requires more investigation.

The objective of this study was to identify and define thrips resistance among a number of pepper accessions, and to analyze the potential effects of this type of resistance on the acquisition and inoculation efficiency of a population of $F$. occidentalis for TSWV isolate BR01.

\section{MATERIALS AND METHODS}

Pepper accessions, thrips population, and virus isolate. Seven Capsicum accessions (Pikante Reuzen, Perla RZ, Mazurka RZ, CPRO-1, CPRO-2, PI 152225, and PI 159236) were used in this study. Accessions PI 159236, PI 152225 (5,6), and Perla RZ (J. Haanstra, personal communication) were known to be resistant to TSWV.

A population of $F$. occidentalis 'IS2' (34), which originated from an infestation on mango in Israel, was used in the transmission studies. This virus-free population was reared on Phaseo- 
lus vulgaris cv. 'Prelude' pods in glass jars at $25 \pm 0.5^{\circ} \mathrm{C}$ under a 16-h light and 8-h dark cycle and supplied with Pinus pollen.

The TSWV isolate BR01 (11) was utilized for mechanical inoculation of the plants and the virus transmission studies. To preserve its virulence, this isolate was maintained by thripsmediated passages on Datura stramonium L. plants.

Assessing thrips resistance levels in pepper accessions. To select a thrips resistant pepper accession, seven accessions were assessed and tested for preference by thrips, for development of feeding damage and for supporting the reproduction of a $F$. occidentalis population. The levels of thrips resistance of the pepper accessions were evaluated in "choice" and "non-choice" tests. In the choice tests, the preference of the thrips and the feeding damage produced were determined in a batch using plants of all accessions. One 3-week-old seedling of each accession was randomly placed in a circle in a thrips-proof cage $(0.75 \times 0.75 \times$ $1 \mathrm{~m})$. This test was made in four replicates. Plants were grown at $26 \pm 4^{\circ} \mathrm{C}$ under a 16-h light and 8-h dark cycle.

Before releasing $75 \mathrm{~F}$. occidentalis females, Pinus pollen was dusted on the primary leaves of all plants to promote the development of the thrips population in the first 2 weeks after their release. Three times a week, larvae and adults were visually counted on the individual plants by inspecting and turning leaves carefully so that the adults did not disperse. The feeding damage was also rated using a relative scale ranging from zero (no damage) up to three (severe damage).

Thrips population development was determined on four accessions in a non-choice test. Six seedlings were placed in a separate thrips-proof cage for each accession, primary leaves were dusted with Pinus pollen, and 30 female $F$. occidentalis were released in each cage. Thrips counts were monitored weekly for each individual plant. This study was repeated two times for each accession.

TABLE 1. Ranking of thrips resistance levels of seven pepper accessions by the product of feeding damage index and cumulative number of thrips on plants in a choice test

\begin{tabular}{lccc}
\hline Accession & $\begin{array}{c}\text { Feeding } \\
\text { damage index }\end{array}$ & $\begin{array}{c}\text { Cumulative number } \\
\text { of thrips }\end{array}$ & Ranking $^{z}$ \\
\hline Pikante Reuzen & 3.0 & $221( \pm 23)$ & 1 \\
PI 159236 & 2.5 & $178( \pm 32)$ & 2 \\
Perla RZ & 1.5 & $118( \pm 9)$ & 3 \\
Mazurka RZ & 1.5 & $105( \pm 18)$ & 4 \\
PI 152225 & 1.0 & $36( \pm 4)$ & 5 \\
CPRO-2 & 0.5 & $37( \pm 13)$ & 6 \\
CPRO-1 & 0.5 & $35( \pm 9)$ & 7 \\
\hline
\end{tabular}

${ }^{\mathrm{z}} 1=$ lowest level of resistance and $7=$ highest level of resistance.
Determining TSWV resistance levels in pepper accessions. For a correct assessment of the effect of thrips resistance on the acquisition and inoculation of TSWV, pepper accessions differing in this property had to be equally susceptible to virus infection.

Ten seedlings of each accession at the six-leaf stage were mechanically inoculated with the TSWV-BR01 isolate. Inocula were prepared from the first systemically infected leaves of thrips inoculated $D$. stramonium plants by triturating $1 \mathrm{~g}$ of leaf material in $10 \mathrm{ml}$ of inoculation buffer $\left(0.01 \mathrm{M} \mathrm{NaH}_{2} \mathrm{PO}_{4}\right.$ and $0.01 \mathrm{M}$ $\mathrm{Na}_{2} \mathrm{HPO}_{4}$, pH 7.0). Plants were reinoculated 4 days later to ensure infection. Another group of 10 seedlings of each accession was inoculated with a 100 -fold diluted extract. Plants were grown in a greenhouse at approximately $22^{\circ} \mathrm{C}$ under a 16-h light and 8-h dark cycle. Symptom development was monitored for 4 weeks postinoculation. Two-leaf disks (1.3 cm i.d.) were taken from two top leaves of each plant, 2 weeks postinoculation. Extracts of these disks were prepared by grinding leaf disks with a Polähne press in phosphate-buffered saline with Tween (PBST) and assayed by enzyme-linked immunosorbent assay (ELISA) for their virus titer.

Effect of TSWV infection on the level of thrips resistance. To elucidate whether TSWV infection affected the thrips resistant phenotype, the effect of virus infection on thrips resistance was assessed using a leaf disk assay. Two virus-free or virus-infected leaf disks $(2.5 \mathrm{~cm}$ i.d. $)$ of a thrips susceptible and resistant accession were placed in petri dishes $(7.5 \mathrm{~cm}$ i.d.) on $1.5 \%$ agar. Each dish was infested with four $F$. occidentalis females. The specimens were counted during the daytime at 30-min intervals. Those present on the two susceptible and resistant disks were separately counted, and those on the agar, wall, and lid were placed in another group designated "off" disk. This monitoring was repeated the next day after transferring the thrips to fresh disks. Each treatment contained six replicates and the experiment was repeated twice. The data were analyzed by Kruskal-Wallis one-way analysis of variance (ANOVA) on the ranks using GENSTAT (21).

Effect of plant resistance to thrips on TSWV acquisition. First instar larvae of $F$. occidentalis, 0 to $4 \mathrm{~h}$ old, were confined to leaf disks $(0.6 \mathrm{~cm}$ i.d. $)$ from systemically infected thrips susceptible or resistant plants with comparable virus titers as shown by ELISA $\left(A_{450}=1.10 \pm 0.08\right)$. Disks were placed on $1.2 \mathrm{ml}$ of $1.5 \%$ agar in 1.5-ml Eppendorf tubes and covered with transparent foil. Larvae had access to these disks for periods of $0.5,1,2,8,24$, or $48 \mathrm{~h}$ and were transferred to noninfected leaf disks ( $2.5 \mathrm{~cm}$ i.d.) of $D$. stramonium (1.5\% agar in a petri dish, $3.4 \mathrm{~cm}$ i.d.) after the acquisition access periods (AAP) until adult emergence. The resulting adults were individually tested for their ability to transmit TSWV on Petunia $\times$ hybrida cv. Blue Magic leaf disks (1.3 cm i.d.) during two successive inoculation access

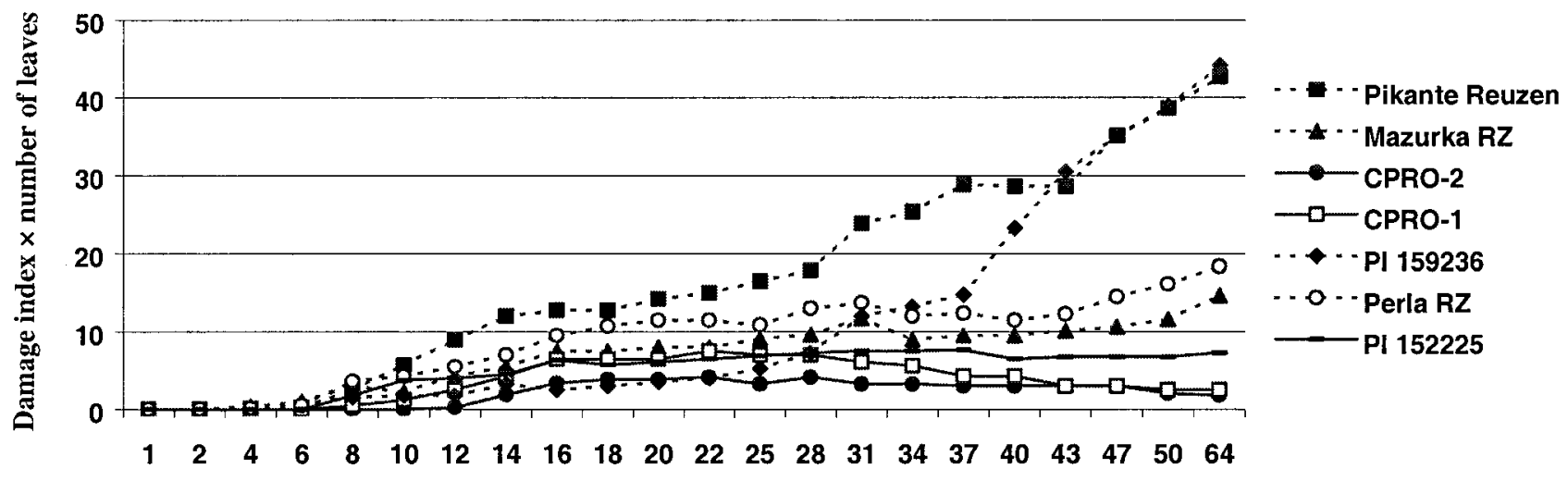

Number of days after thrips release

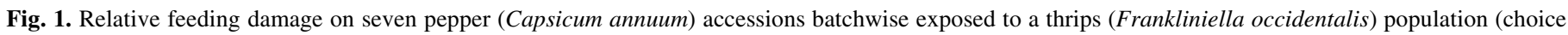
test), expressed as the multiplication of the damage index and the number of leaves exhibiting symptoms (damage index $\times$ number of leaves). 
periods (IAPs) of $48 \mathrm{~h}$ (37). After these IAPs, the disks were incubated in a 24-well plate on water at $27^{\circ} \mathrm{C}$ for $72 \mathrm{~h}$ for development of local lesions. Approximately 20 thrips were used for each AAP, and the experiments were repeated three times. The thrips' sex ratio was similar in each treatment (female/male $=6: 5$ ). Virus acquisition efficiencies were analyzed as binomially distributed variables using GENSTAT.

Effect of plant resistance to thrips on TSWV inoculation. First instar larvae of $F$. occidentalis, 0 to $4 \mathrm{~h}$ old, were given an AAP of $48 \mathrm{~h}$ on leaf disks from systemically infected $D$. stramonium leaves to acquire TSWV. The disks $(2.5 \mathrm{~cm}$ i.d.) were placed on $1.5 \%$ agar in a petri dish $(3.4 \mathrm{~cm}$ i.d.) covered with transparent foil. After the AAP, the larvae were transferred to virus-free leaf disks of $D$. stramonium until they became adult. The ability of each adult to transmit virus on leaf disks $(1.3 \mathrm{~cm}$ i.d.) of thrips susceptible and resistant plants was tested using IAPs of $0.5,1,2$, $8,16,24$, or $48 \mathrm{~h}$. Approximately 35 thrips were used for each IAP, and the experiment was repeated twice. The thrips' sex ratio was similar in each treatment (female/male $=6: 5$ ). Fifty adults, given an IAP of $48 \mathrm{~h}$ on Petunia spp. leaf disks were used to determine the percentage of viruliferous thrips in the population used for this experiment. Inoculation efficiencies were compared and analyzed as binomially distributed variables using GENSTAT.

ELISA. Virus titers in extracts of leaf disks from mechanically inoculated plants or thrips inoculated leaf disks were tested by targeting the nucleocapsid protein of TSWV using ELISA with antiserum produced in rabbits (23). This assay was also used to determine the virus titer in leaves used as virus source for acquisition feeding.

Wells of Nunc Maxisorp F96 immunoplates (Greiner, Alphen aan de Rijn, the Netherlands) were incubated with $150 \mu \mathrm{l}$ of $1 \mu \mathrm{g}$ of $\mathrm{IgG}$ per $\mathrm{ml}$ of coating buffer $(0.05 \mathrm{M}$ sodium carbonate, $\mathrm{pH}$ 9.6) for $2 \mathrm{~h}$ at $37^{\circ} \mathrm{C}$. After rinsing the plates two times with tap water and once with demineralized water, leaf disk extracts were added to the wells. The extracts were prepared by grinding leaf disks in PBST (0.14 M NaCl, $2 \mathrm{mM} \mathrm{KCl}, 2 \mathrm{mM} \mathrm{KH} \mathrm{PO}_{4}, 8 \mathrm{mM}$ $\mathrm{Na}_{2} \mathrm{HPO}_{4} \cdot 2 \mathrm{H}_{2} \mathrm{O}$, and $0.05 \%$ Tween 20). After incubation of the extracts for $2 \mathrm{~h}$ at $37^{\circ} \mathrm{C}$ and rinsing the plates, $150 \mu \mathrm{l}$ of $1 \mu \mathrm{g}$ of conjugate per $\mathrm{ml}$ of PBST was added to each well and incubated overnight at $4^{\circ} \mathrm{C}$. After rinsing the plates, nucleocapsid proteins were detected by adding $150 \mu \mathrm{l}$ of $1 \mathrm{mg}$ of $p$-nitrophenyl phosphate disodium per $\mathrm{ml}$ of diethanolamine buffer (0.01 M, $\mathrm{pH} 9.6)$. Absorbance values were read on a Bio-Tek Instruments EL 312 ELISA-reader (Greiner, Alphen aan de Rijn, the Netherlands) at $405 \mathrm{~nm}$. Samples giving an ELISA reading higher than the average of six healthy control readings plus three times the standard deviation were considered positive and those with lower readings were negative.

\section{RESULTS}

Thrips resistance levels in seven pepper accessions. The seven pepper accessions tested showed considerable differences in resistance to thrips (Table 1). When plants of all accessions were batchwise exposed to thrips in a choice test, feeding damage was

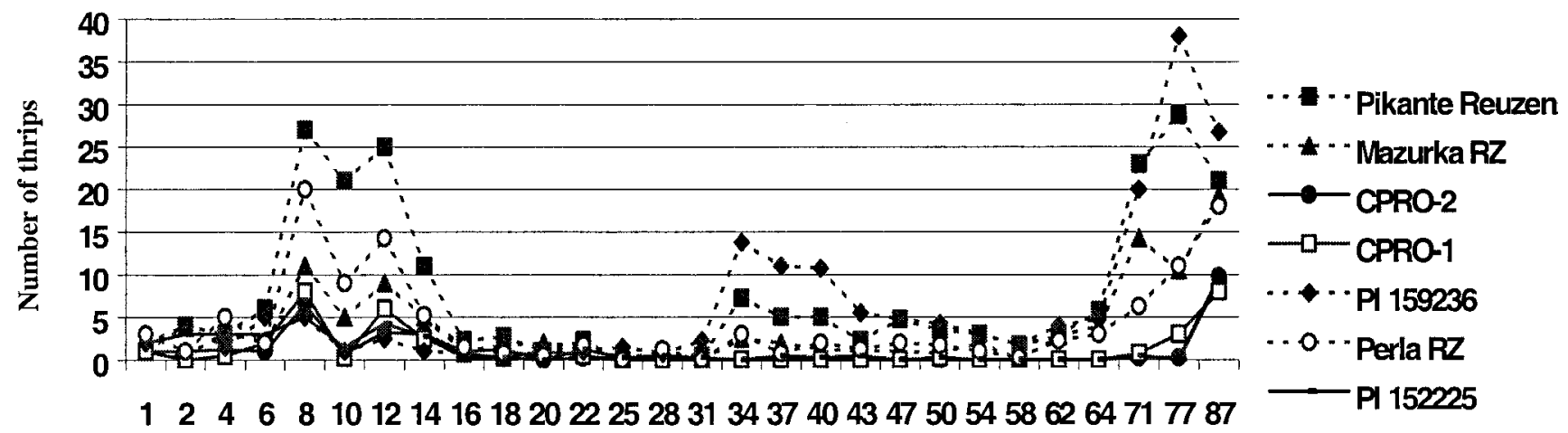

Number of days after thrips release

Fig. 2. Mean thrips counts on plants of seven pepper accessions batchwise exposed to a thrips (Frankliniella occidentalis) population (choice test).

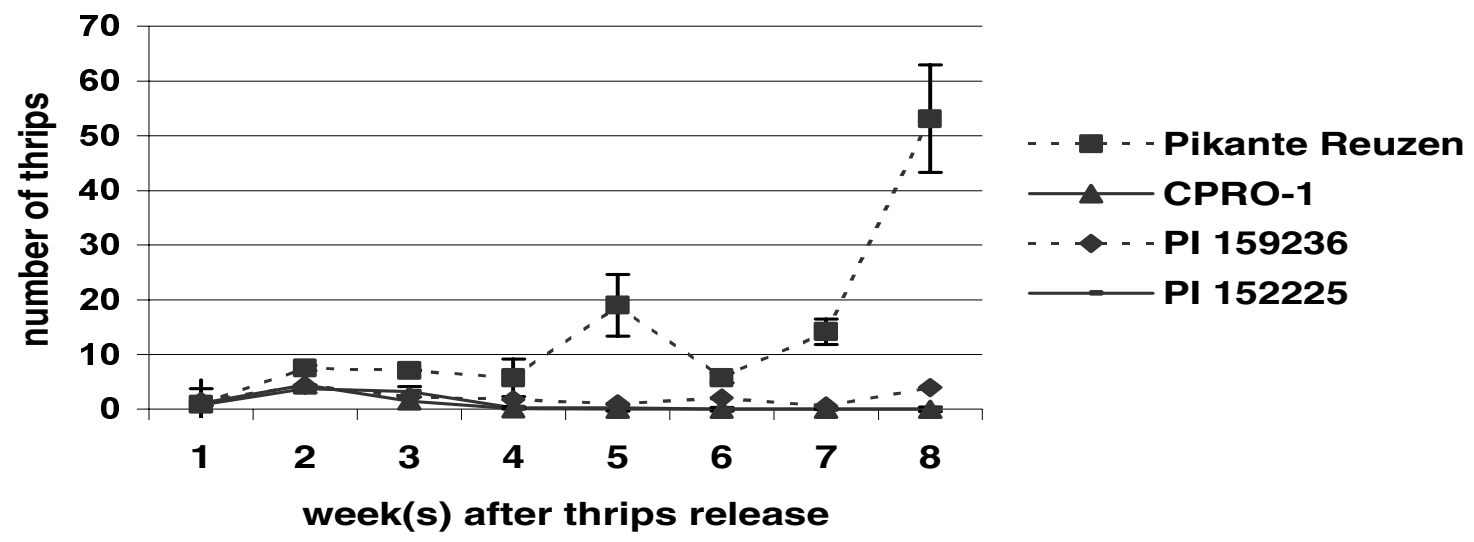

Fig. 3. Mean thrips counts on plants of four pepper accessions separately enclosed in thrips-proof cages (non-choice test). Thirty thrips were released on all accessions. Bars indicate the standard error of the mean. 
observed on all accessions irrespective of whether they were preferred by thrips (Figs. 1 and 2; Table 1). Severe feeding damage was recorded on the accessions Pikante Reuzen and PI 159236, with moderate damage on Mazurka RZ and Perla RZ, and only mild damage on CPRO-1, CPRO-2, and PI 152225 (Fig. 1; Table 1). Damage on the accessions which had only mild damage recorded did not increase 2 weeks after the release of thrips.

The numbers of thrips monitored on the plants of each accession fluctuated with time, with three prominent peaks in weeks 2 , 5, and 10 after release of the adults (Fig. 2). The sharp increase of the thrips numbers after week 10 coincided with the start of the flowering of the plants. Addition of Pinus pollen on the primary leaves did not alter the preference of thrips for the pepper accessions studied (data not shown).

Thrips resistance levels of two of the most promising accessions, CPRO-1 and PI 152225, were further analyzed in a nonchoice test, along with the most thrips susceptible accessions Pikante Reuzen and PI 159236 in a manner preventing any dispersal of thrips between the accessions. F. occidentalis reproduced most efficiently on plants of Pikante Reuzen, while only a few thrips accumulated on plants of the accessions CPRO-1, PI 152225, and PI 159236 during the entire test period of 8 weeks (Fig. 3). The high numbers of thrips found on PI 159236 in the choice test (Fig. 2; Table 1) might be explained by dispersal of thrips from the more preferred accessions or by reproduction of these dispersing adults on this accession. Results obtained enabled us to rank the accessions from 1 through 7 (Table 1) for their level of thrips resistance as based on feeding damage and host preference. Results from the non-choice experiments in which population development was measured support this ranking (Fig. 3).

Determining TSWV resistance levels in pepper accessions. The accessions Pikante Reuzen, Mazurka RZ, CPRO-1, and CPRO-2 were equally susceptible to TSWV, as they had similar virus titers 2 weeks after mechanical inoculation (Table 2). Accessions Perla RZ, PI 152225, and PI 159236 on the other hand, were not systemically infected as expected because these accessions contained the Tsw resistance gene (6). Similar results were obtained for plants inoculated with a 100-fold diluted inoculum.

Based on the results summarized in Tables 1 and 2, accession CPRO-1 was identified as the most thrips resistant line and accession Pikante Reuzen as the most thrips susceptible line with both being equally susceptible to TSWV.

TABLE 2. Disease symptoms of TSWV and its titers determined by enzymelinked immunosorbent assay (ELISA) in systemically infected leaves of seven pepper (Capsicum) accessions 2 weeks after mechanical inoculation

\begin{tabular}{llc}
\hline Pepper accession & \multicolumn{1}{c}{ Symptoms } & ELISA reading $^{z}$ \\
\hline Pikante Reuzen & Mosaic, chlorotic veins & $1.23 \pm 0.08$ \\
Mazurka RZ & Mosaic, chlorotic veins & $1.36 \pm 0.07$ \\
CPRO-2 & Leaf curl, chlorotic veins & $1.38 \pm 0.12$ \\
CPRO-1 & Leaf curl, chlorotic veins & $1.19 \pm 0.07$ \\
PI 159236 & None & $0.04 \pm 0.01$ \\
Perla RZ & None & $0.05 \pm 0.01$ \\
PI 152225 & None & $0.00 \pm 0.01$ \\
\hline
\end{tabular}

${ }^{\mathrm{z}}$ Mean ELISA reading ( $A_{450}$ values) of 10 plants \pm the standard error of the mean (sem). The threshold value of the control leaf disks was $0.11 \pm 0.01$.

TABLE 3. Percent dispersal of Frankliniella occidentalis over leaf disks of thrips resistant accession CPRO-1 (TR) and thrips susceptible accession Pikante Reuzen (TS), either healthy or TSWV infected in a petri dish

\begin{tabular}{llll}
\hline & TR disk & TS disk & "off” disk ${ }^{\mathrm{y}}$ \\
\hline Noninfected & $22 \pm 7 \mathrm{a}^{\mathrm{z}}$ & $55 \pm 7 \mathrm{~b}$ & $23 \pm 5 \mathrm{a}$ \\
Infected & $24 \pm 17 \mathrm{a}$ & $64 \pm 15 \mathrm{~b}$ & $12 \pm 2 \mathrm{c}$ \\
\hline
\end{tabular}

y Thrips found on the agar, wall, and lid were scored as "off" disk.

${ }^{\mathrm{z}}$ Different letters in a row indicate significant differences between values $(P$ $<0.05)$.
Effect of TSWV infection on the level of thrips resistance. To address the value of thrips resistance for virus control, it is of prime importance to evaluate whether virus infection would alter this trait. This possibility was determined in a leaf disk assay. Thrips preferred to feed on leaf disks of the thrips susceptible accession over disks from the thrips resistant accession (Table 3) regardless of infection status. Although less thrips were found "off" the infected disks, the ratio of $F$. occidentalis preferring the susceptible over the resistant leaf disks was not significantly affected by virus infection (Table 3). The experiments also demonstrate that thrips resistance can be reliably monitored using leaf disk assays.

Effect of vector resistance on TSWV acquisition and inoculation. To assess to what extent thrips resistance may affect TSWV acquisition and inoculation, and therefore virus spread in the field, the effect of this resistance on both properties was analyzed in leaf disk assays. The acquisition efficiencies obtained on the disks from thrips susceptible and resistant plants were plotted for each accession as function of the AAP (Fig. 4). For both accessions, approximately $70 \%$ of the thrips transmitted the virus after an AAP of $24 \mathrm{~h}$, allowing reliable comparisons between the thrips susceptible and resistant accessions. Virus acquisition on thrips susceptible and resistant leaf disks did not differ significantly for all AAPs $(P>0.10)$. No differences in mortality were found during the periods that the larvae had acquisition access to infected leaf disks of the thrips susceptible or resistant accession.

Inoculation efficiencies to disks of the thrips susceptible accession and Petunia spp. after exposure to individual viruliferous thrips showed that 74 and $72 \%$ of the adults, respectively, transmitted the virus, allowing us to make reliable comparisons between inoculation of thrips susceptible and resistant leaf disks. Identical inoculation efficiencies were found for both accessions when short IAPs were given, but they differed significantly after IAPs of 24 and $48 \mathrm{~h}(P<0.01$; Fig. 5), indicating that vector resistance reduced virus inoculation significantly only after long IAPs. No differences in mortality were recorded between thrips feeding on thrips susceptible or resistant leaf disks.

\section{DISCUSSION}

Results show that the seven pepper accessions varied considerably with respect to thrips resistance levels. The differences in thrips resistance were defined by three parameters, quantity of direct feeding damage, host preference, and thrips population development on the accessions. The initial feeding damage produced on the resistant accessions CPRO-1 and PI 152225 after release of the adults did not increase. This might indicate that, besides a poor population development on the resistant accessions, disper-

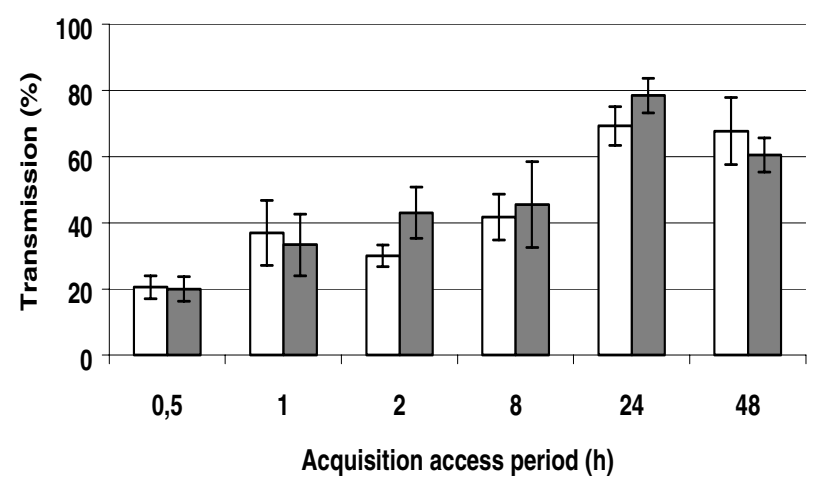

Fig. 4. Mean Tomato spotted wilt virus acquisition efficiencies by Frankliniella occidentalis from leaf disks of a thrips susceptible (Pikante Reuzen; white bars) and a thrips resistant (CPRO-1; dark bars) accession as function of the acquisition access period. Error-bars indicate the standard error of the mean. 
sal of the thrips between the susceptible and resistant plants was low and/or that the thrips left the resistant plants without feeding. The almost complete absence of feeding scars on the resistant accession, showing that the plant is a less suitable host for thrips, does not result in a reduced acquisition of TSWV and gives only a reduction of the inoculation efficiency after long IAPs. Apparently, the (duration of) probing activity of the thrips is not affected by thrips resistance and is long enough to transmit the virus.

The acquisition efficiencies found for both pepper accessions were not affected by thrips resistance and were in agreement with those reported for Impatiens sp. (38), known to be a permissive host. The inoculation efficiency was found to be similar when short IAPs were given. Long IAPs resulted in a significant lower number of disks from the thrips resistant accession infected with TSWV than of disks from the susceptible accession. This indicates that virus incidence will be lower when the thrips continuously feed on plants of thrips resistant crops, but this remains to be studied under field conditions.

The minimum time required for successful inoculation on thrips susceptible and resistant phenotype in this study was $1 \mathrm{~h}$ (Fig. 5), comparable to the values found for GBNV transmission by Thrips palmi to groundnut (35). However, this time span is considerably longer than the minimum IAPs reported for the transmission of TSWV to Petunia spp. and Nicotiana rustica by $F$. occidentalis and Thrips tabaci $(38,22)$. In our study, $9 \%$ of the disks from thrips resistant plants and $10 \%$ of the disks from susceptible plants became infected after an IAP of $8 \mathrm{~h}$, whereas 80 and $65 \%$ of the Petunia spp. and D. stramonium leaf disks, respectively, became infected after an IAP of $5 \mathrm{~h}$ (38). These differences in inoculation efficiencies might be explained by different adaptation rates and feeding responses of the adults to these host plants. The thrips resistant pepper accession used is likely to be a less suitable host for adult feeding than Petunia spp. and D. stramonium, resulting in lower number of TSWV infections per unit of time.

After IAPs of $16 \mathrm{~h}$ or longer, the percentage of infected thrips susceptible leaf disks increased rapidly whereas a slower increase was observed for thrips resistant disks. The explanation for this phenomenon might be that the adults adapted more readily to the susceptible pepper accession than to the resistant accession. This quicker adaptation would then result in a different feeding behavior on the first accession leading to more effective inoculations. It is not known which activity in the feeding behavior, e.g., penetration, saliva production, or food ingestion, is less or more frequently performed as a result of this adaptation. In case thrips make more penetrations on resistant plants in search for suitable feeding sites, it can be concluded that the virus is not inoculated during stylet penetration, but during a later activity by which cells remain sufficiently viable to replicate the virus.

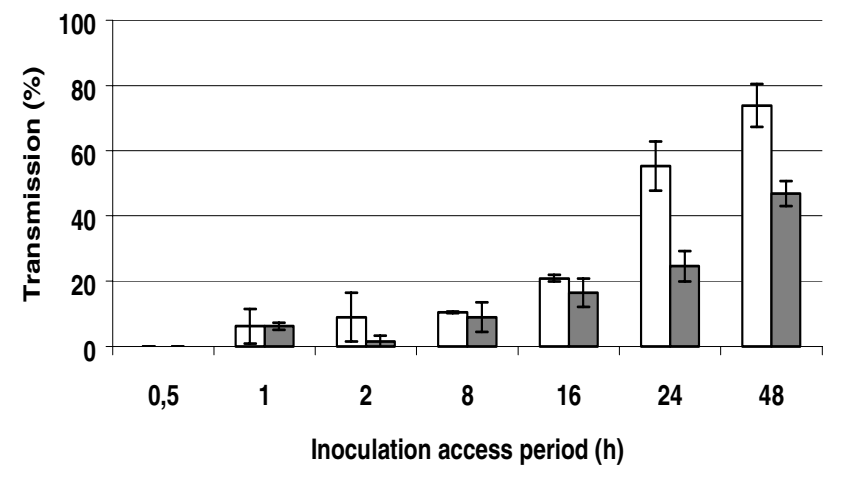

Fig. 5. Mean Tomato spotted wilt virus inoculation efficiencies of Frankliniella occidentalis on leaf disks of a thrips susceptible (Pikante Reuzen; white bars) and thrips resistant accession (CPRO-1; dark bars) as function of the inoculation access period. Error-bars indicate the standard error of the mean.
The lower inoculation efficiency found after long IAPs on the resistant pepper accession is in contrast with the higher inoculation rate found on a thrips resistant versus a thrips susceptible chrysanthemum (33). This increase was explained by the assumption that a higher number of punctures were made by thrips on the resistant plants. These results are compatible with those obtained in arena tests in which the transmission rate of a nonpersistently transmitted virus to a nonhost for its (aphid) vector was significantly higher than to hosts of the vector (40). It remains to be analyzed why such, apparently host-dependent differences exist.

Vector resistance in plants has often been associated with a decrease of virus incidence. Decreases have been found for Cowpea mottle virus, Wheat streak mosaic virus, Grapevine fanleaf virus, Potato leaf roll virus, Tomato yellow leaf curl virus, and Rice ragged stunt virus which are transmitted by beetles, mites, nematodes, aphids, whiteflies, and planthoppers, respectively $(1,4,8,18,19,20,24,28)$. On the other hand, an increase of Cowpea aphid-borne mosaic virus (CABMV) incidence has been demonstrated in an aphid resistant cowpea cultivar (3). Differences in incidences may be determined by the number of incoming vectors, reproduction and mortality rates, dispersal in the crop, and the number of punctures made by the vector on a plant. These parameters controlling virus incidences in vector resistant crops are not fully understood.

The results presented in this study demonstrate that an operational level of thrips resistance does not necessarily lead to impeded TSWV acquisition or inoculation during the transmission of this virus. Although a thrips resistant accession was selected based on a lower preference, decreased feeding damage, as well as decreased reproduction, our study reveals that feeding damage cannot be used as a reliable marker for thrips resistance when the thrips spend only limited periods of time on the resistant plants. Due to the lower reproduction rate and lower preference of thrips for the resistant plants, as found in this study, beneficial effects of thrips resistance might still be expected under field conditions. As the pepper accessions were screened for their level of resistance to thrips feeding, to thrips population development, and to host preference, these accessions represent suitable material for studying the underlying mechanism(s) of possible effects of vector resistance on virus spread under field conditions.

\section{ACKNOWLEDGMENTS}

We thank J. Haanstra (Rijk Zwaan, de Lier, the Netherlands) and A. Balkema-Boomstra (Plant Research International, Wageningen, the Netherlands) for providing Capsicum seeds; and F. Tjallingii and F. Kindt for their stimulating discussions. This research was financially supported by the Foundation of Technical Research (STW), of the Netherlands Organization for Scientific Research (NWO) (project WBI.4827).

\section{LITERATURE CITED}

1. Allen, D. J., Thottappilly, G., and Rossel, H. W. 1982. Cowpea mottle virus: Field resistance and seed transmission in virus-tolerant cowpea. Ann. Appl. Biol. 100:331-336.

2. Amin, P. W. 1985. Apparent resistance of groundnut cultivar Robut 33-1 to bud necrosis disease. Plant Dis. 69:718-719.

3. Atiri, G. I., Ekpo, E. J. A., and Thottappilly, G. 1984. The effect of aphid-resistance in cowpea on infestation and development of Aphis craccivora and the transmission of cowpea aphid-borne mosaic virus. Ann. Appl. Biol. 104:339-346.

4. Berlinger, M. J., Dahan, R., and Mordechi, S. 1986. Breeding tomatoes resistant to the transmission of tomato yellow leaf curl virus by Bemisia tabaci. Phytoparasitica 14:158-159.

5. Black, L. L., Hobbs, H. A., and Gatti, J. M. 1991. Tomato spotted wilt virus resistance in Capsicum chinense PI 152225 and 159236. Plant Dis. 75:863.

6. Boiteux, L. S., and de Ávila, A. C. 1994. Inheritance of a resistance specific to tomato spotted wilt tospovirus in Capsicum chinense 'PI 159236'. Euphytica 75:139-142.

7. Boiteux, L. S., Nagata, T., Dutra, W. P., and Fonseca, M. E. N. 1993. 
Sources of resistance to tomato spotted wilt virus (TSWV) in cultivated and wild species of Capsicum. Euphytica 67:89-94.

8. Bouquet, A. 1981. Resistance to grape fanleaf virus in Muscadine grape inoculated with Xiphinema index. Plant Dis. 65:791-793.

9. Brødsgaard, H. F. 1994. Insecticide resistance in European and African strains of western flower thrips (Thysanoptera; Thripidae) tested in a new residue-on-glass test. J. Econ. Entomol. 87:1141-1146.

10. Daughtrey, M. L., Jones, R. K., Moyer, J. W., Daub, M. E., and Baker, J. R. 1997. Tospoviruses strike the greenhouse industry, INSV has become a major pathogen on flower crops. Plant Dis. 81:1220-1230.

11. de Ávila, A. C., Huguenot, C., Resende, R. de O., Kitajima, E. W., Goldbach, R. W., and Peters, D. 1990. Serological differentiation of 20 isolates of tomato spotted wilt virus. J. Gen. Virol. 71:2801-2807.

12. Fery, R. L., and Schalk, J. M. 1991. Resistance in pepper (Capsicum annuиm L.) to western flower thrips [Frankliniella occidentalis (Pergande)]. Hortscience 26:1073-1074.

13. German, T. L., Ullman, D. E., and Moyer, J. W. 1992. Tospoviruses: Diagnosis, molecular biology, phylogeny and vector relationships. Annu. Rev. Phytopathol. 30:315-348.

14. Jahn, M., Paran, I., Hoffmann, K., Radwanski, E. R., Livingstone, K. D., Grube, R. C., Aftergoot, E., Lapidot, M., and Moyer, J. 2000. Genetic mapping of the Tsw locus for resistance to the tospovirus tomato spotted wilt virus in Capsicum spp. and its relationship to the Sw-5 gene for resistance to the same pathogen in tomato. Mol. Plant-Microbe Interact. 13:673-682.

15. Kumar, N. K. K., Ullman, D. E., and Cho, J. J. 1993. Evaluation of Lycopersicon germ plasm for tomato spotted wilt tospovirus resistance by mechanical and thrips transmission. Plant Dis. 77:938-941.

16. Kumar, N. K. K., Ullman, D. E., and Cho, J. J. 1995. Frankliniella occidentalis (Thysanoptera: Thripidae) landing and resistance to tomato spotted wilt tospovirus among Lycopersicon accessions with additional comments on Thrips tabaci (Thysanoptera: Thripidae) and Trialeurodes vaporariorum (Homoptera: Aleyrodidae). Environ. Entomol. 24:513520.

17. Laviña, A., Aramburu, J., Riudavets, J., Arnó, J., and Moriones, E. 1993. Epidemiology of TSWV on tomato in Northeast Spain. Abstract of the IXth Int. Congr. Virol. Glasgow, Scotland.

18. Martin, T. J., Harvey, T. L., Bender, C. G., and Seifers, D. L. 1984. Control of wheat streak mosaic virus with vector resistant wheat. Phytopathology 74:963-964.

19. Martin, T. J., Harvey, T. L., Bender, C. G., Seifers, D. L., and Hatchett, J. H. 1983. Wheat curl mite resistant wheat germplasm. Crop Sci. 23:809.

20. Parejarearn, A., Lapis, D. B., and Hibino, H. 1984. Reaction of rice varieties to rice ragged stunt virus (RSV) infection by three brown planthopper (BPH) biotypes. Int. Rice Res. Newsl. 9:7-8.

21. Payne, R. W., Lane, P. W., Digby, P. G. N., Harding, S. A., Leech, P. K., Morgan, G. W., Todd, A. D., Thompson, R., Tunnicliffe Wilson, G., Welham, S. J., and White, R. P. 1993. Genstat Reference Manual No. 3, 5th ed. Clarendon Press, Oxford, U.K.

22. Razvyazkina, G. M. 1953. The importance of the tobacco thrips in the development of outbreaks of tip chlorosis of makhorka. Doklady Vsesoyuznoi Akademii Sel'sko-kho-zyaistvennykh Nauk 18:27-31 (in Russian). (Abstr) Rev. Appl. Entomol. 146:A42.

23. Resende, R. de O., De Ávila, A. C., Goldback, R. W., and Peters, D. 1991. Comparison of polyclonal antisera in the detection of tomato spotted wilt virus using the double antibody sandwich and cocktail ELISA. J. Phytopathol. 132:46-56.

24. Rizvi, S. A. H., and Raman, K. V. 1983. Effect of glandular trichomes on the spread of potato virus Y (PVY) and potato leaf roll virus (PLRV) in the field. Pages 162-163 in: Proc. Int. Congr. Res. Potato in the year 2000, Lima, Peru.

25. Robb, K. L., Newman, J, Virzi, J. K., and Parrella, M. P. 1995. Insecticide resistance in western flower thrips. Pages 33-40 in: Thrips Biology and Management. B. L. Parker, M. Skinner, and T. Lewis, eds. Plenum Press, New York.

26. Roselló, S., Diez, M. J., Jorda, C., and Nuez, F. 1997. Utilization of Capsicum sp. resistance to TSWV in pepper breeding. Capsicum and Eggplant Newsl. 16:87-90.

27. Sakimura, K. 1963. Frankliniella fusca, an additional vector for the tomato spotted wilt virus, with notes on Thrips tabaci, another vector. Phytopathology 53:412-415.

28. Shukla, D. D., Ward, C. W., and Brunt, A. A. 1994. Epidemiology and control strategies. Pages 287-321 in: Potyviridae. CAB International, Wallingford, U.K.

29. Stevens, M. R., Scott, S. J., and Gergerich, R. C. 1992. Resistance to tomato spotted wilt virus (TSWV). Page 78 in: Proc. for the Tomato Quality Workshop and Tomato Breeders Roundtable, Sarasota, FL.

30. Todd, J. W., Culbreath, A. K., and Brown, S. L. 1996. Dynamics of vector populations and progress of tomato spotted wilt disease relative to insecticide use in peanuts. Acta Hortic. 431:483-490.

31. Ullman, D. E., German, T. L., Sherwood, J. L., Westcot, D. M., and Canone, F. A. 1993. Tospovirus replication in insect vector cells: Immuno-cytochemical evidence that the non structural protein encoded by the S RNA of tomato spotted wilt tospovirus is present in thrips vector cells. Phytopathology 83:456-463.

32. Ullman, D. E., Sherwood, J. L., and German, T. L. 1997. Thrips as vectors of plant pathogens. Pages 539-565 in: Thrips as Crop Pests. T. Lewis, ed. CAB International, Wallingford, U.K.

33. van de Wetering, F. 1999. Effects of thrips feeding on tospovirus transmission in chrysanthemum. Ph.D. Thesis. Wageningen University, Wageningen, the Netherlands.

34. van de Wetering, F., van der Hoek, M., Goldbach, R., Mollema, C., and Peters, D. 1999. Variation in tospovirus transmission between populations of Frankliniella occidentalis (Thysanoptera; Thripidae). Bull. Entomol. Res. 89:579-588.

35. Vijayalakshmi, K. 1994. Transmission and ecology of Thrips palmi Karny, the vector of peanut bud necrosis virus. Ph.D. Thesis. Andhra Pradesh Agricultural University, Hyderabad, India.

36. Wijkamp, I., Almarza, N., Goldbach, R., and Peters, D. 1995. Distinct levels of specificity in thrips transmission of tospoviruses. Phytopathology 85:1069-1074.

37. Wijkamp, I., and Peters, D. 1993. Determination of the median latent period of two tospoviruses in Frankliniella occidentalis, using a novel leaf disk assay. Phytopathology 83:986-991.

38. Wijkamp, I., van de Wetering, F., Goldbach, R., and Peters, D. 1996. Transmission of tomato spotted wilt virus by Frankliniella occidentalis; median acquisition and inoculation access period. Ann. Appl. Biol. 129:303-313.

39. Wijkamp, I., van Lent, J., Kormelink, R., Goldbach, R., and Peters, D. 1993. Multiplication of tomato spotted wilt virus in its insect vector, Frankliniella occidentalis. J. Gen. Virol. 74:341-349.

40. Yuan, C., and Ullman, D. E. 1996. Comparison of efficiency and propensity as measures of vector importance in zucchini yellow mosaic potyvirus transmission by Aphis gossypii and A. craccivora. Phytopathology 86:698-703.

41. Zhao, G., Liu, W., Brown, J. M., and Knowles, O. 1995. Insecticide resistance in field and laboratory strains of western flower thrips (Thysanoptera; Thripidae). J. Econ. Entomol. 88:1164-1170. 